\title{
Seasonal water quality monitoring of the Bhairab River at Noapara industrial area in Bangladesh
}

\author{
Abu Shamim Khan ${ }^{1} \cdot$ Abdul Hakim $^{1} \cdot$ Waliullah $^{2} \cdot$ Mizanur Rahman $^{3} \cdot$ Bablu Hira Mandal $^{4} \cdot$ Abdullah-Al-Mamun $^{4}$. \\ Firoz Ahammed ${ }^{5}$
}

(c) Springer Nature Switzerland AG 2019

\begin{abstract}
s
The Bhairab River is located in south-western part of Bangladesh which is acting as a source of irrigation, drinking, industrial process water and also sinks for waste water. This study area is stands on this river which is situated at Noapara municipality under Abhaynagar upazila of Jessore district in Bangladesh. This river receives wastewater from various sources along its way which are discharging as industrial effluents, municipal sewage, household waste, clinical waste and oils. It was monitored the seasonal variability of surface water quality and impact of waste water on river which is provide an updated report on present status of the Bhairab River. Water samples were collected in the year 2016-2017 during winter, summer and rainy seasons from six different sampling stations. It was measured arsenic, iron, manganese, lead, chromium and cadmium by HG-AAS and flame-AAS methods respectively. Water quality index was calculated from five parameters at each sampling stations in three seasons individually. Average concentrations of metals in three seasons were compared with DoE standard for inland surface water in Bangladesh. This study is indicated that water quality was relatively good in rainy season due to huge discharge volume of fresh water and less effect of tidal flow. The seasonal pollution load index order was summer $>$ winter $>$ rainy season respectively. Critical condition of water quality observed in summer season due to low discharge volume fresh water, effect of tidal flow and waste water runoff from densely populated catchment.
\end{abstract}

Keywords River $\cdot$ Arsenic $\cdot$ Iron $\cdot$ Manganese $\cdot$ Season

\section{Introduction}

Bangladesh is a land of river. More than 405 rivers are passing through this country including 53 international rivers [1]. Rivers constitute the main inland water body for domestic, industrial and agricultural activities and often carry large quantity of municipal sewage, industrial waste and seasonal runoff from agriculture field $[2,3]$. The long discharge of untreated municipal sewerage, industrial effluents, and agricultural residue into the river water can caused water pollution which may influence human health problems [4,5]. Now a day's river water pollution is reached alarming level in Bangladesh due to man-made action [6]. Heavy metals are natural elements which are occurring in the environment and earth crust. Contamination of metal in surface water body is not safe for using drinking, cooking, fish culture and irrigation purposes [7]. Metal pollution may effect on aquatic ecosystem biodiversity and reduce species abundance through reproductive impairment $[8,9]$. Surface water pollution is a serious environmental problem in our country due to rapid urbanization, industrialization, low economic condition,

\footnotetext{
$\triangle$ Abu Shamim Khan, abuskhan2000@yahoo.com | ${ }^{1}$ Environmental Laboratory, Asia Arsenic Network, Arsenic Center, Benapole Road, Krishnobati, Pulerhat, Jessore 7400, Bangladesh. ${ }^{2}$ Molecular Ecology and Metagenomics Laboratory, ICDDRB, Mohakhali, Dhaka 1212, Bangladesh. ${ }^{3}$ Department of Microbiology, Jessore University of Science and Technology, Jessore 7400, Bangladesh. ${ }^{4}$ Department of Chemistry, Jessore University of Science and Technology, Jessore 7400, Bangladesh. ${ }^{5}$ Department of Chemistry, Abdur Razzak College, Jessore 7400, Bangladesh.
} 
lack of awareness and natural disaster [10]. Metals are non-biodegradable and it can be necessary for plant at certain levels but it can be toxic when it will exceed the specific threshold level [11]. River water quality depends on concentration level of pollutants in effluents and discharge volume of wastes from different types of industries, agrochemicals used in agriculture, seasonal water flow and dilution capability of the river system [12]. Surface water pollution at riverside area has a dangerously caught up the regional economical development and affected this areas people's daily life [13]. Most of the regional river water quality has been failed to meet the permissible limit of national standard due to the excessive volume of pollutant, lack of regular water quality monitoring, loose policies of national surface water management authority and climate change problems [14]. So, perfect evaluation of river water pollution status is a great significance for protection and management of surface water environment.

The Bhairab River is origin from Chuadanga district which is passing through Jhenaidah, Narail, Khulna and Jessore district in Bangladesh [15, 16]. The Bhairab River is connecting with the Rupsha River near Khulna city. It is passing about $242 \mathrm{~km}$ through 5 districts of Khulna division in Bangladesh $[15,16]$. Noapara is an industrial zone in south-west part of Bangladesh which is situated $70 \mathrm{~km}$ upstream from mangrove forest Sundarbans [17]. Previous studies were reported that heavy metals are available in river water [13, 18-21]. River water quality monitoring is very important for protecting surface water safety and aquatic life. This research objective is to detect the heavy metals in river water and evaluation of pollution status in three seasons. It will be contributed some updated information about heavy metals in the Bhairab river.

\section{Materials and methodology}

The present study was conducted on the Bhairab River which is passing through Noapara municipal area at Abhainagar upazila in Jessore district. Noapara municipal town occupies a total area of $25.11 \mathrm{~km}^{2}$ with a population of around 73,006 [22]. Many jute processing, cement manufacturing, fertilizer manufacturing, construction materials and automobile oil storage are available in this area. The sampling point was selected on the basis of connection between river and pollution sources. The water samples were collected from the estuaries of 5 different sampling points. GIS maps and sample information is described in the Table 1 (Fig. 1).

The Bhairab River water quality monitoring was conducted since September 2016 to April 2017. It was monitored the seasonal variation of water quality in winter, summer and rainy seasons. Water sample was collected in a $100 \mathrm{~mL}$ plastic bottle for metal analysis from six sampling stations which were preserved with $2 \mathrm{~mL}$ of $6 \mathrm{~N}$ nitric acid $[23,24]$. Prior to sample collection, all of sample bottles were washed with $10 \%$ nitric acid and di-ionized water. Arsenic, iron, manganese, lead, cadmium and chromium were tested by HG-AAS and flame-AAS methods respectively [25]. For evaluating the pollution status of river water in three seasons pollution load index (PLI) was calculated by the following equation (Contamination factor (CF) = $\mathrm{C}_{\text {Sample }} / \mathrm{C}_{\text {reference value for river water }}$ Pollution Load Index (PLI)

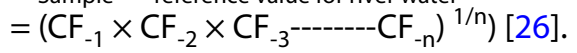

\section{Results and discussion}

It was monitored seasonal river water quality in winter, summer and rainy season at five sampling stations of the Bhairab River. Concentration of arsenic, iron, manganese, lead, cadmium and chromium in river water expressed in the Table 2. Among all the metals measured in river water, iron concentration was the highest and arsenic concentration was lowest in three seasons. On the other hand lead, cadmium and chromium concentration was not detected in three seasons which concentration showed below detection level of flame-AAS method. It was observed that an arsenic, iron and manganese content in river water were a significant difference between three seasons. The variation of metals contents in river water are basically different sampling points and seasons.

Table 1 General information of study area

\begin{tabular}{|c|c|c|c|c|c|c|c|}
\hline Sample ID & Sampling station & $\begin{array}{l}\text { Name of } \\
\text { municipality }\end{array}$ & District & Water source & $\begin{array}{l}\text { Sources of discharge } \\
\text { waste water }\end{array}$ & Longitude & Latitude \\
\hline$A$ & Shankarpasha & Noapara & Jessore & River & Household & 89.4015 & 23.0288 \\
\hline B & WAPDA power plant & Noapara & Jessore & River & Industrial & 89.4056 & 23.0252 \\
\hline $\mathrm{C}$ & Chitra fertilizer & Noapara & Jessore & River & Household & 89.4082 & 23.0228 \\
\hline $\mathrm{D}$ & Amin fertilizer & Noapara & Jessore & River & Industrial & 89.4104 & 23.0193 \\
\hline $\mathrm{E}$ & SAF leather & Noapara & Jessore & River & Industrial & 89.4116 & 23.0173 \\
\hline $\mathrm{F}$ & Taltala power plant & Noapara & Jessore & River & Industrial & 89.4139 & 23.0138 \\
\hline
\end{tabular}




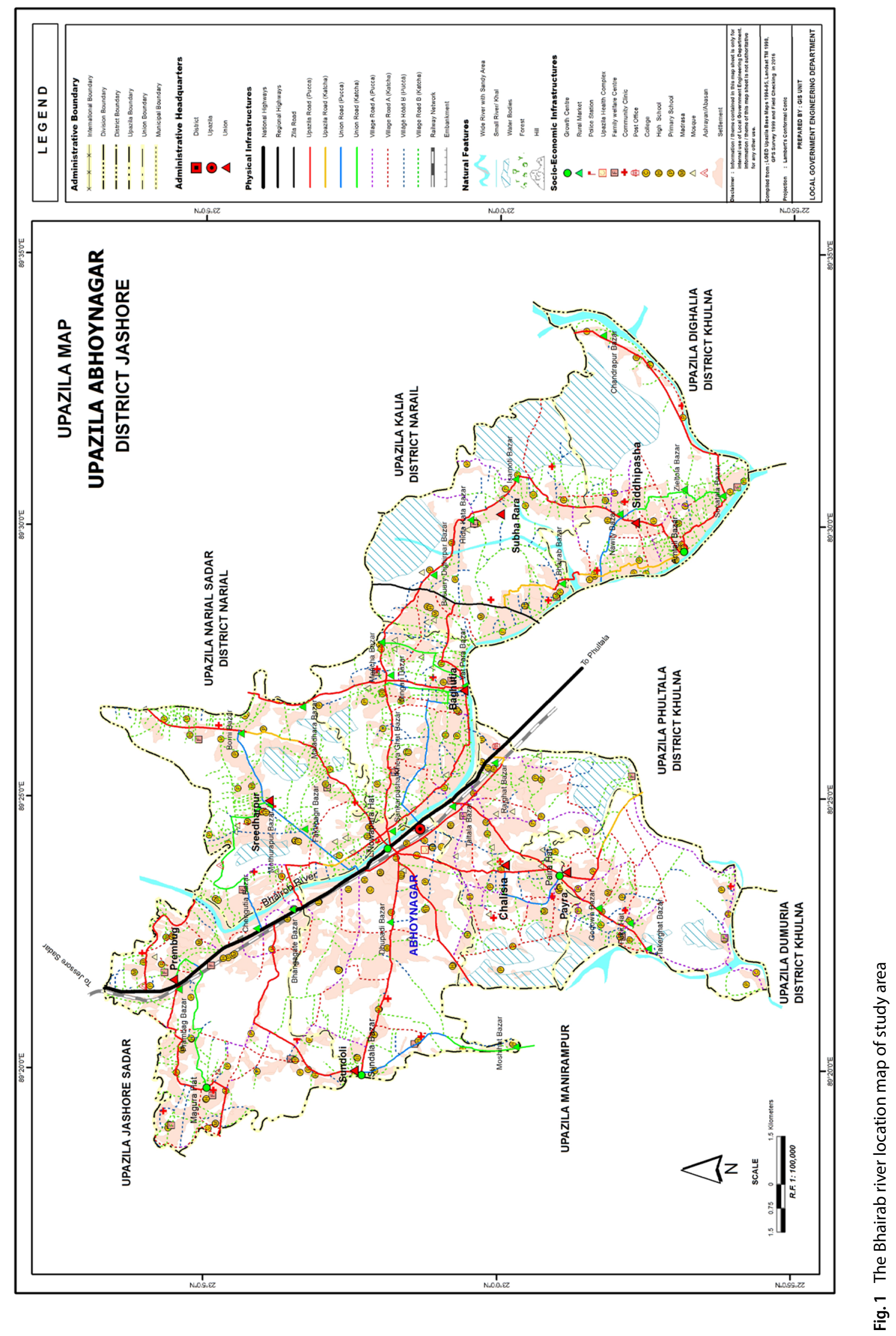


Table 2 Concentration of arsenic, iron and manganese in winter, summer and rainy season

\begin{tabular}{|c|c|c|c|c|c|c|c|c|c|}
\hline \multirow[t]{2}{*}{ Sample ID } & \multicolumn{3}{|c|}{ Conc. of arsenic $\left(\mathrm{mg} \mathrm{L}^{-1}\right)$} & \multicolumn{3}{|c|}{ Conc. of iron $\left(\mathrm{mg} \mathrm{L}^{-1}\right)$} & \multicolumn{3}{|c|}{ Conc. of manganese $\left(\mathrm{mg} \mathrm{L}^{-1}\right)$} \\
\hline & $\begin{array}{l}\text { Winter } \\
\text { season }\end{array}$ & $\begin{array}{l}\text { Summer } \\
\text { season }\end{array}$ & Rainy season & $\begin{array}{l}\text { Winter } \\
\text { season }\end{array}$ & $\begin{array}{l}\text { Summer } \\
\text { season }\end{array}$ & $\begin{array}{l}\text { Rainy } \\
\text { season }\end{array}$ & $\begin{array}{l}\text { Winter } \\
\text { season }\end{array}$ & $\begin{array}{l}\text { Summer } \\
\text { season }\end{array}$ & Rainy season \\
\hline$A$ & $0.012 \pm 0.002$ & $0.021 \pm 0.002$ & $0.006 \pm 0.001$ & $3.21 \pm 0.04$ & $5.13 \pm 0.03$ & $2.27 \pm 0.04$ & $0.20 \pm 0.02$ & $0.35 \pm 0.03$ & $0.11 \pm 0.02$ \\
\hline B & $0.011 \pm 0.001$ & $0.020 \pm 0.001$ & $0.007 \pm 0.001$ & $3.23 \pm 0.04$ & $5.25 \pm 0.04$ & $2.29 \pm 0.02$ & $0.20 \pm 0.02$ & $0.34 \pm 0.03$ & $0.10 \pm 0.01$ \\
\hline $\mathrm{C}$ & $0.013 \pm 0.001$ & $0.021 \pm 0.001$ & $0.007 \pm 0.001$ & $3.24 \pm 0.05$ & $5.60 \pm 0.04$ & $2.30 \pm 0.02$ & $0.18 \pm 0.03$ & $0.32 \pm 0.02$ & $0.10 \pm 0.01$ \\
\hline $\mathrm{D}$ & $0.013 \pm 0.001$ & $0.025 \pm 0.001$ & $0.008 \pm 0.001$ & $3.26 \pm 0.07$ & $5.62 \pm 0.03$ & $2.35 \pm 0.05$ & $0.21 \pm 0.04$ & $0.30 \pm 0.02$ & $0.13 \pm 0.01$ \\
\hline $\mathrm{E}$ & $0.017 \pm 0.002$ & $0.027 \pm 0.001$ & $0.012 \pm 0.001$ & $3.59 \pm 0.04$ & $5.78 \pm 0.04$ & $2.48 \pm 0.04$ & $0.24 \pm 0.04$ & $0.37 \pm 0.04$ & $0.16 \pm 0.01$ \\
\hline $\mathrm{F}$ & $0.016 \pm 0.001$ & $0.024 \pm 0.001$ & $0.010 \pm 0.001$ & $3.36 \pm 0.04$ & $5.44 \pm 0.04$ & $2.25 \pm 0.03$ & $0.23 \pm 0.03$ & $0.32 \pm 0.02$ & $0.14 \pm 0.01$ \\
\hline Maximum & 0.017 & 0.027 & 0.012 & 3.59 & 5.78 & 2.48 & 0.24 & 0.37 & 0.16 \\
\hline Minimum & 0.011 & 0.020 & 0.006 & 3.21 & 5.13 & 2.25 & 0.18 & 0.30 & 0.10 \\
\hline Average & 0.014 & 0.023 & 0.008 & 3.32 & 5.52 & 2.32 & 0.21 & 0.33 & 0.12 \\
\hline SD & 0.002 & 0.003 & 0.002 & 0.14 & 0.31 & 0.08 & 0.02 & 0.03 & 0.02 \\
\hline $\begin{array}{l}\text { Aver- } \\
\text { age } \pm \text { SD }\end{array}$ & $0.014 \pm 0.002$ & $0.023 \pm 0.003$ & $0.008 \pm 0.002$ & $3.32 \pm 0.14$ & $5.52 \pm 0.31$ & $2.32 \pm 0.08$ & $0.21 \pm 0.02$ & $0.33 \pm 0.03$ & $0.12 \pm 0.02$ \\
\hline $\begin{array}{l}\text { WHO } \\
\text { standard } \\
\text { for drink- } \\
\text { ing water }\end{array}$ & 0.010 & & & 0.30 & & & 0.10 & & \\
\hline $\begin{array}{l}\text { DoE } \\
\text { standard } \\
\text { for river } \\
\text { water }\end{array}$ & 0.050 & & & 0.30 & & & 0.10 & & \\
\hline
\end{tabular}

Trace level of arsenic is toxic for human body which can causes arsenicosis diseases [27]. It can enter our body through water and food system which systems should safe from arsenic. Average concentration of arsenic was found $0.014 \pm 0.002 \mathrm{mg} \mathrm{L}^{-1}, 0.023 \pm 0.003 \mathrm{mg} \mathrm{L}^{-1}$ and $0.008 \pm 0.002 \mathrm{mg} \mathrm{L}^{-1}$ in winter, summer and rainy season which were lower than DoE standard $\left(0.05 \mathrm{mg} \mathrm{L}^{-1}\right)$ for river water in Bangladesh (Tables 2, 3; Fig. 2) [28]. On the other hand average concentration of arsenic was higher than WHO standard for drinking water in winter and summer season (Table 3; Fig. 2) [24]. In summer season average concentration of arsenic was higher than winter and rainy season due to low discharge volume of fresh water, dissolved surface sediments and huge discharge volume of household and industrial waste into the river. Maximum concentration of arsenic was detected $0.017 \pm 0.002 \mathrm{mg} \mathrm{L}^{-1}, 0.027 \pm 0.001 \mathrm{mg} \mathrm{L}^{-1}$ and $0.012 \pm 0.001 \mathrm{mg} \mathrm{L}^{-1}$ in winter, summer and rainy season at $F$ station which may causes for discharging of tannery waste from leather industry (Table 2; Fig. 2). According to DoE standard this river water was safe from arsenic which may use for drinking with conventional treatment, cooking, and irrigation and fish culture purposes.

Table 3 Comparison of river water quality with DoE standard for river water and WHO standard for drinking water

\begin{tabular}{|c|c|c|c|c|c|c|c|c|c|}
\hline \multirow[t]{2}{*}{ Sample ID } & \multicolumn{3}{|c|}{ Conc. of arsenic $\left(\mathrm{mg} \mathrm{L}^{-1}\right)$} & \multicolumn{3}{|c|}{ Conc. of iron $\left(\mathrm{mg} \mathrm{L}^{-1}\right)$} & \multicolumn{3}{|c|}{ Conc. of manganese $\left(\mathrm{mg} \mathrm{L}^{-1}\right)$} \\
\hline & $\begin{array}{l}\text { Winter } \\
\text { season }\end{array}$ & $\begin{array}{l}\text { Summer } \\
\text { season }\end{array}$ & $\begin{array}{l}\text { Rainy sea- } \\
\text { son }\end{array}$ & $\begin{array}{l}\text { Winter } \\
\text { season }\end{array}$ & $\begin{array}{l}\text { Summer } \\
\text { season }\end{array}$ & $\begin{array}{l}\text { Rainy sea- } \\
\text { son }\end{array}$ & $\begin{array}{l}\text { Winter } \\
\text { season }\end{array}$ & $\begin{array}{l}\text { Summer } \\
\text { season }\end{array}$ & Rainy season \\
\hline$A$ & $A-, B+$ & $A-, B+$ & $A-, B-$ & $A+, B+$ & $A+, B+$ & $A+, B+$ & $A+, B+$ & $A+, B+$ & $A+, B+$ \\
\hline B & $\mathrm{A}-, \mathrm{B}+$ & $A-, B+$ & $A-, B-$ & $A+, B+$ & $A+, B+$ & $A+, B+$ & $A+, B+$ & $A+, B+$ & $A-, B-$ \\
\hline $\mathrm{C}$ & $\mathrm{A}-, \mathrm{B}+$ & $A-, B+$ & $A-, B-$ & $\mathrm{A}+, \mathrm{B}+$ & $A+, B+$ & $A+, B+$ & $\mathrm{A}+, \mathrm{B}+$ & $A+, B+$ & $A-, B-$ \\
\hline $\mathrm{D}$ & $A-, B+$ & $A-, B+$ & $A-, B-$ & $A+, B+$ & $A+, B+$ & $A+, B+$ & $A+, B+$ & $A+, B+$ & $A+, B+$ \\
\hline $\mathrm{E}$ & $A-, B+$ & $A-, B+$ & $A-, B+$ & $\mathrm{A}+, \mathrm{B}+$ & $A+, B+$ & $A+, B+$ & $\mathrm{A}+, \mathrm{B}+$ & $A+, B+$ & $A+, B+$ \\
\hline $\mathrm{F}$ & $\mathrm{A}-, \mathrm{B}+$ & $A-, B+$ & $A-, B-$ & $A+, B+$ & $A+, B+$ & $A+, B+$ & $A+, B+$ & $A+, B+$ & $A+, B+$ \\
\hline
\end{tabular}

B+: Exceed WHO standard limit for drinking water; B-: Bellow WHO standard limit for drinking water; A+: Exceed DoE standard limit for river water; A-: Bellow DoE standard limit for river water 
Fig. 2 Arsenic concentration graph

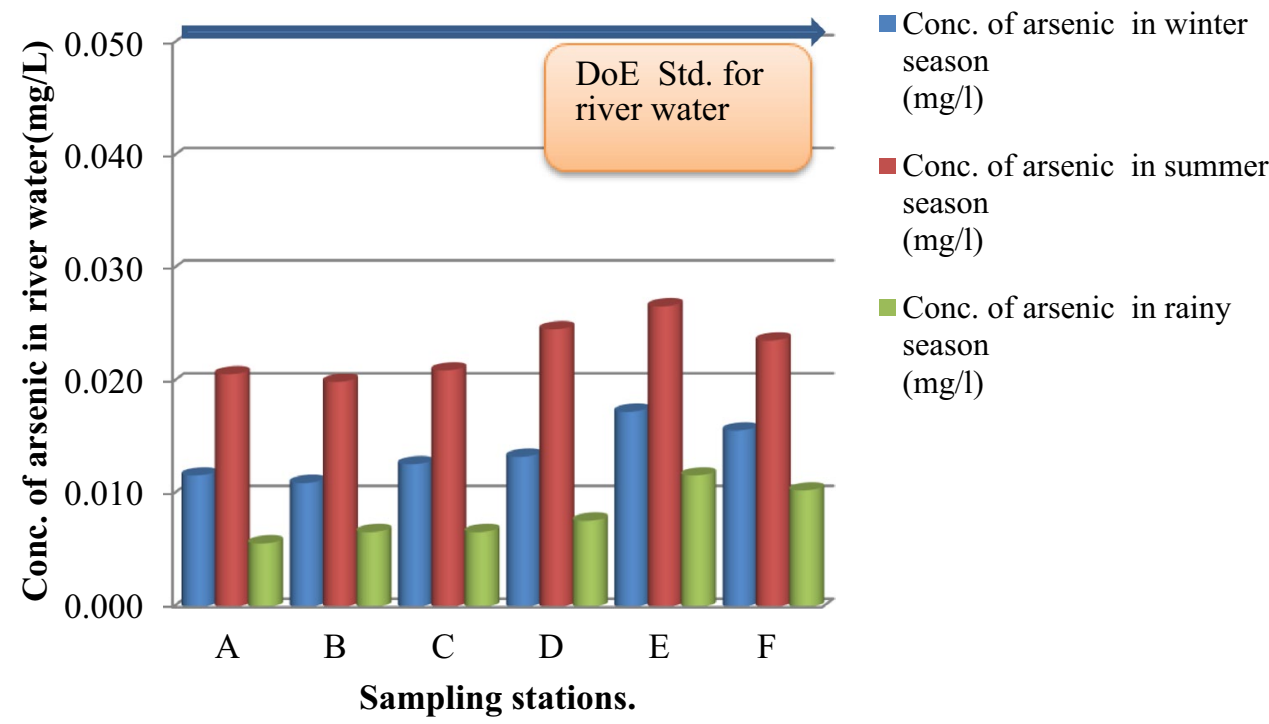

Iron is a common metal in surface sediments which can dissolve in surface water. It is not health hazard but it creates bitter taste in drinking and color spot making in laundry [29]. It can damage heating system and boiler pipe. According to WHO and DoE standard iron concentration should be maintained with in $0.30 \mathrm{mg} \mathrm{L}^{-1}$ for drinking without any conventional treatment $[24,28]$. Average concentration of iron was found $3.32 \pm 0.14 \mathrm{mg} \mathrm{L}^{-1}$, $5.52 \pm 0.31 \mathrm{mg} \mathrm{L}^{-1}$ and $2.32 \pm 0.08 \mathrm{mg} \mathrm{L}^{-1}$ in winter, summer and rainy season which were higher than WHO standard for drinking water and DoE standard for river water in Bangladesh (Tables 2, 3; Fig. 3) [24, 28]. Average concentration of iron was higher than winter and rainy season due to low discharge volume of fresh water and high temperature. Maximum concentration of iron was detected $3.59 \pm 0.04 \mathrm{mg} \mathrm{L}^{-1}, 5.78 \pm 0.04 \mathrm{mg} \mathrm{L}^{-1}$ and
$2.48 \pm 0.04 \mathrm{mg} \mathrm{L}^{-1}$ at $\mathrm{F}$ station in three seasons due to dissolved iron from industrial waste (Table 2; Fig. 3). It is indicated that this river water is not suitable for drinking and industrial process without any treatment.

Manganese is a toxic metal in surface sediments which can dissolve in surface water. It has adverse effects on health which is caused by poor intake or over exposure of manganese through water and food [30]. Manganese concentration should be maintain $0.10 \mathrm{mg} \mathrm{L}^{-1}$ which is recommended by WHO for drinking water and DoE for river water [24, 28].

Average concentration of manganese was measured $0.21 \pm 0.02 \mathrm{mg} \mathrm{L}^{-1}, 0.33 \pm 0.031 \mathrm{mg} \mathrm{L}^{-1}$ and $0.12 \pm 0.02 \mathrm{mg} \mathrm{L}^{-1}$ in winter, summer and rainy season which were higher than WHO and DoE standard (Tables 2, 3 ; Fig. 4) [24, 28]. Maximum concentration of manganese
Fig. 3 Iron concentration graph
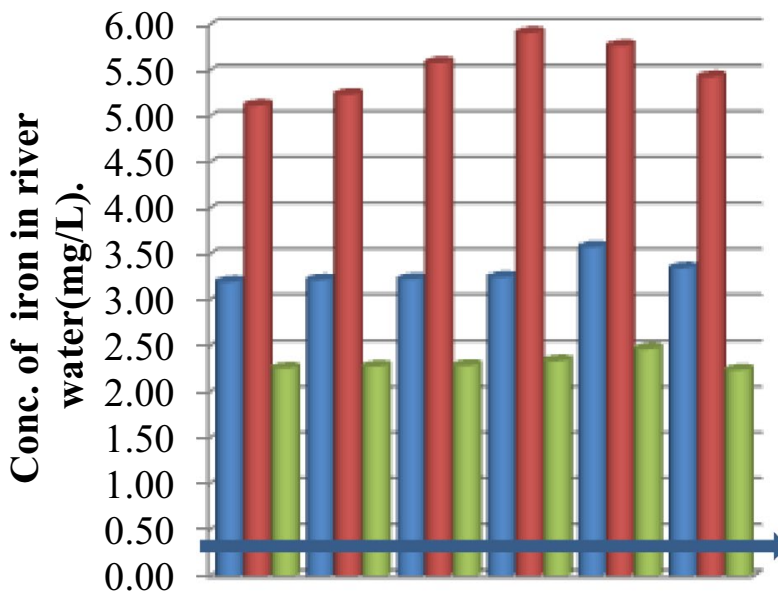

$\begin{array}{llllr}\text { A } & \text { B } & \text { C } & \text { D } \quad \text { E } \\ & \text { Sampling stations }\end{array}$
- Conc. of iron in winter season $(\mathrm{mg} / \mathrm{l})$

- Conc. of iron in summer season $(\mathrm{mg} / \mathrm{l})$

Conc. of iron in rainy season $(\mathrm{mg} / \mathrm{l})$

WHO \& DoE Std. for drinking and river water 
Fig. 4 Manganese concentration graph

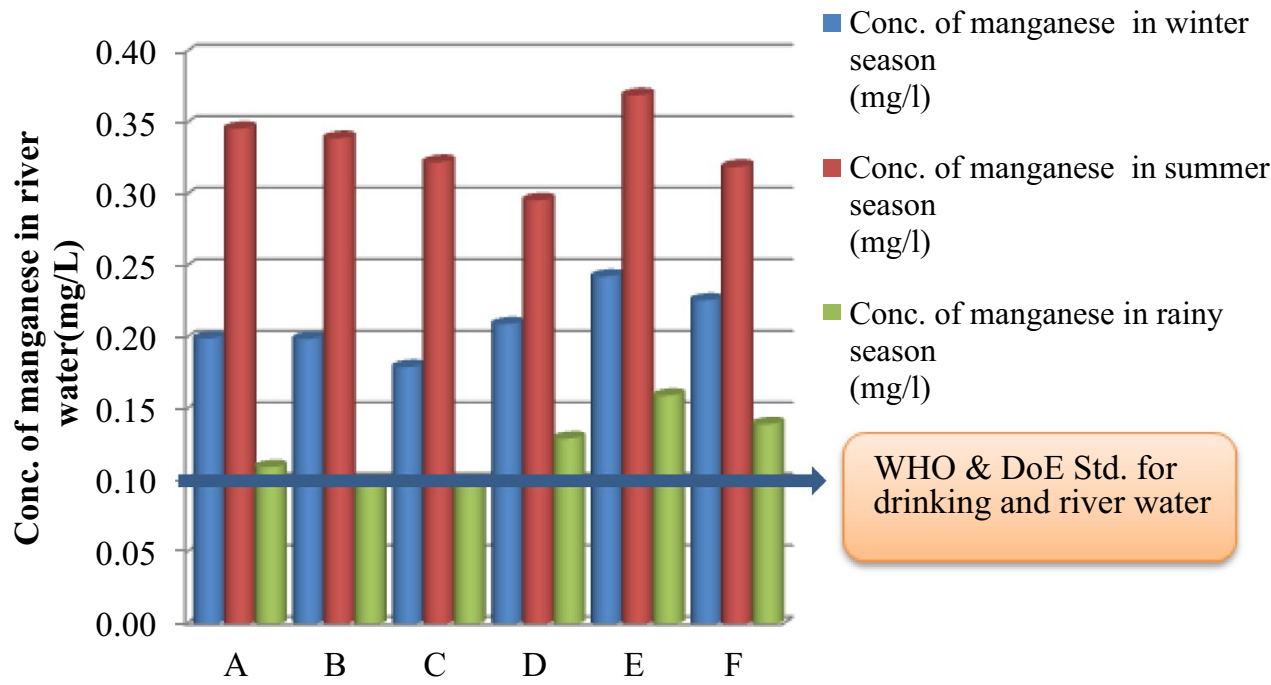

Sampling stations was found $0.24 \pm 0.04 \mathrm{mg} \mathrm{L}^{-1}, 0.37 \pm 0.04 \mathrm{mg} \mathrm{L}^{-1}$ and $0.16 \pm 0.01 \mathrm{mg} \mathrm{L}^{-1}$ at $\mathrm{F}$ station in three seasons due to mixing of industrial and municipal waste (Table 2; Fig. 4). Average concentration of manganese was monitored higher than winter and rainy season due to tidal flow and low discharge volume of freshwater. It is alarming for aquatic life and human health (Table 4).

Average concentration of arsenic, iron and manganese was higher in summer season than winter and rainy season due to tidal flow, low discharge volume of fresh water, dissolved surface sediments, household and industrial waste discharge into the river. On the other hand metal contents in river was very low in rainy season than winter and summer season due to huge discharge volume fresh water and less effect of tidal flow. Highest concentration of arsenic, iron and manganese showed at F station in all season which may causes by discharging of tannery waste from leather industry (Fig. 5).

Table 4 Pollution load index and its status of river water

\begin{tabular}{|c|c|c|c|c|c|c|c|}
\hline \multirow[t]{2}{*}{ Sample ID } & \multirow{2}{*}{$\begin{array}{l}\text { Season } \\
\text { Stations }\end{array}$} & \multicolumn{2}{|l|}{ Winter } & \multicolumn{2}{|l|}{ Summer } & \multicolumn{2}{|l|}{ Rainy } \\
\hline & & $\begin{array}{l}\text { Pollution index } \\
\text { (PI) }\end{array}$ & $\begin{array}{l}\text { Classification of } \\
\text { pollution }\end{array}$ & $\begin{array}{l}\text { Pollution index } \\
\text { (PI) }\end{array}$ & $\begin{array}{l}\text { Classification of } \\
\text { pollution }\end{array}$ & $\begin{array}{l}\text { Pollution index } \\
\text { (PI) }\end{array}$ & $\begin{array}{l}\text { Classification of } \\
\text { pollution }\end{array}$ \\
\hline$A$ & Shankar pasha & 2.16 & $\begin{array}{l}\text { Severely pol- } \\
\text { luted }\end{array}$ & 3.50 & $\begin{array}{l}\text { Severely pol- } \\
\text { luted }\end{array}$ & 1.46 & $\begin{array}{l}\text { Moderately pol- } \\
\text { luted }\end{array}$ \\
\hline B & $\begin{array}{l}\text { WAPDA power } \\
\text { plant }\end{array}$ & 2.16 & $\begin{array}{l}\text { Severely pol- } \\
\text { luted }\end{array}$ & 3.55 & $\begin{array}{l}\text { Severely pol- } \\
\text { luted }\end{array}$ & 1.46 & $\begin{array}{l}\text { Moderately pol- } \\
\text { luted }\end{array}$ \\
\hline $\mathrm{C}$ & Chitra fertilizer & 2.14 & $\begin{array}{l}\text { Severely pol- } \\
\text { luted }\end{array}$ & 3.72 & $\begin{array}{l}\text { Severely pol- } \\
\text { luted }\end{array}$ & 1.47 & $\begin{array}{l}\text { Moderately pol- } \\
\text { luted }\end{array}$ \\
\hline $\mathrm{D}$ & Amin fertilizer & 2.21 & $\begin{array}{l}\text { Severely pol- } \\
\text { luted }\end{array}$ & 3.87 & $\begin{array}{l}\text { Severely pol- } \\
\text { luted }\end{array}$ & 1.55 & $\begin{array}{l}\text { Moderately pol- } \\
\text { luted }\end{array}$ \\
\hline$E$ & SAF leather & 2.46 & $\begin{array}{l}\text { Severely pol- } \\
\text { luted }\end{array}$ & 3.92 & $\begin{array}{l}\text { Severely pol- } \\
\text { luted }\end{array}$ & 1.68 & $\begin{array}{l}\text { Moderately pol- } \\
\text { luted }\end{array}$ \\
\hline $\mathrm{F}$ & $\begin{array}{l}\text { Taltala power } \\
\text { plant }\end{array}$ & 2.30 & $\begin{array}{l}\text { Severely pol- } \\
\text { luted }\end{array}$ & 3.64 & $\begin{array}{l}\text { Severely pol- } \\
\text { luted }\end{array}$ & 1.52 & $\begin{array}{l}\text { Moderately pol- } \\
\text { luted }\end{array}$ \\
\hline Maximum & & 2.46 & & 3.92 & & 1.68 & \\
\hline Minimum & & 2.14 & & 3.50 & & 1.46 & \\
\hline Average & & 2.24 & $\begin{array}{l}\text { Severely pol- } \\
\text { luted }\end{array}$ & 3.70 & $\begin{array}{l}\text { Severely pol- } \\
\text { luted }\end{array}$ & 1.52 & $\begin{array}{l}\text { Moderately pol- } \\
\text { luted }\end{array}$ \\
\hline SD & & 0.12 & & 0.17 & & 0.09 & \\
\hline Average $\pm S D$ & & $2.24 \pm 0.12$ & & $3.70 \pm 0.17$ & & $1.52 \pm 0.09$ & \\
\hline
\end{tabular}




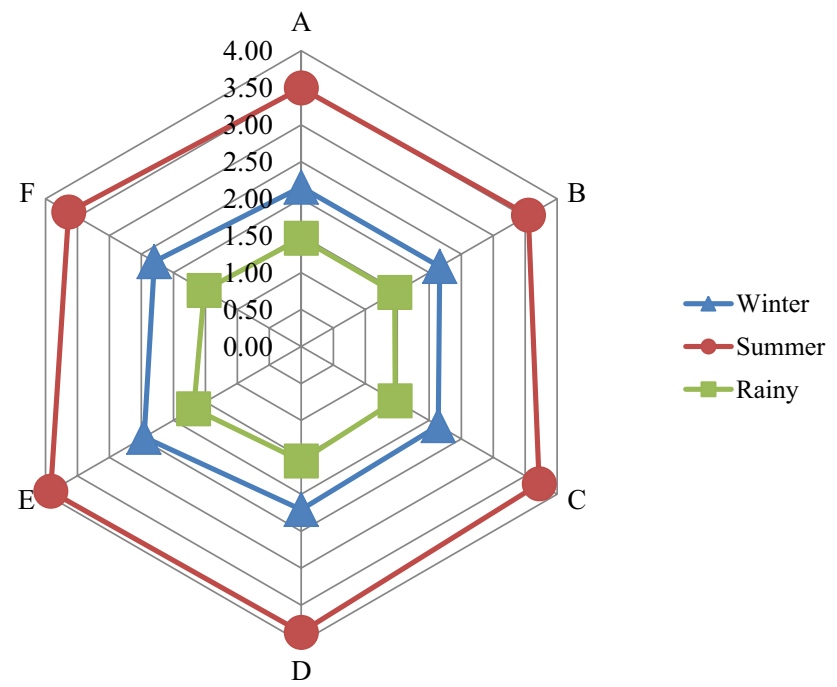

Fig. 5 Pollution status graph

\section{Conclusion}

This study illustrated that arsenic contents in river water was safe level but iron and manganese contents were exceeding that permissible limit of river water quality which may effect on river sediment and aquatic eco system. River is the most available source of surface water in this area which water quality safety is very essential. Municipal corporation, district administration and department of environment can take initiatives to protect river water pollution from untreated industrial and municipal waste which waste treatment is important before discharging into the river. They can conduct awareness on river water pollution sources and its protection system and make regulation on central waste treatment unit for municipal and industrial waste treatment.

Acknowledgements The Authors are thankful to the Noapara Municipal Corporation, Jashore University of Science and Technology \& Asia Arsenic Network (AAN), Bangladesh for their kind permission to use their research field and laboratory facilities for this study.

Funding This research was conducted by authors own funding.

\section{Compliance with ethical standards}

Conflict of interest The authors declare that they have no conflict of interest.

\section{References}

1. Water Science et al (2011) Bangladesh Water Development Board, Dhaka, Bangladesh

2. Khan FA, Ansari AA (2005) Eutrophication: an ecological vision. Bot Rev 71:449-482

3. Tapp JJ, Wharfe J, Hunt S (1996) Toxic impacts of waste on the aquatic environment. Royal Society of Chemistry, London

4. Darapu SSK, Sudhakar B, Krishna KSR, Rao PV, Sekhar MC (2011) Determining water quality index for the evaluation of water quality of river Godavari. Int J Environ Res Appl 1:18-174

5. Simoes FS, Moreira AB, Bisinoti MC, Gimenez SMN, Yabe MJS (2008) Water quality index as a simple indicator of aquaculture effects on aquatic bodies. Ecol Ind 8:476-484

6. Alam JB, Hossain A, Khan SK, Banik BK, Islam MR, Muyen Z, Rahman MH (2007) Deterioration of water quality of Surma River. Environ Monit Assess 134(1-3):233-242

7. Kibria G, Yousuf Haroon AK, Nugegoda D, Rose G (eds) (2010) Climate change and chemicals: environmental and biological aspects. New India Publishing Agency, New Delhi, p 460

8. Wu RSS, Lau TC, Fung WKM, Koa PH, Leung KMY (2007) An artificial mussel for monitoring heavy metals in a marine environment. Environ Pollut 145:104e110

9. Kibria G, Lau TC, Wu RSS (2012) Innovative 'artificial mussels' technology for assessing spatial and temporal distribution of metals in Goulburn-Murray catchments waterways, Victoria, Australia: effects of climate variability (dry vs. wet years). Environ Int 50C:38e46

10. Sarker MAK (2005) Study on the accumulation and seasonal variation of trace metals in water, sediment and some fishes of the Buriganga river. M.Sc. thesis, Department of Zoology, University of Dhaka, Dhaka, Bangladesh

11. Qishlaqi A, Farid Moore F (2007) Statistical analysis of accumulation and sources of heavy metals occurrence in 11. Agricultural soils of Khoshk River banks, Shiraz, Iran. Am Eurasian J Agric Environ Sci 2(5):565-573

12. DHV (1998) Meghna Estuary Study. Main report for BWDB, Dhaka, Bangladesh, $\mathrm{p} 1$

13. Ahmed F, Aziz MA, Alam MJ, Hakim MA, Khan MAS, Rahman MA (2015) Impact on aquatic environment for water pollution in the vahirab river. Int J Eng Sci 4(8):56-62

14. Barnwal P, Mishra S, Singhal SK (2015) Risk assessment and analysis of water quality in Ramgarh Lake, India. J Integr Sci Technol 03(01):22-27

15. Manik MR et al. (2015) Bangladesher Nodnodi; Bortoman Gotiprokiti, Kotha Prokashoni, Banglabazar, Dhaka, Bangladesh, pp 60-62, ISBN:9847012004364

16. Ashok B et al. (2011) Bangladesher Nodikosh, Gotidhara Prokashoni, Banglabazar, Dhaka, Bangladesh, pp 248-332, ISBN:978-984-8945-17-9

17. Rahman SMB et al (2014) Seasonal nutrient distribution in the Rupsha-Passur tidal river system of the Sundarbans mangrove forest, Bangladesh. Ecol Process 3(18):2-11

18. Samad MA, Mahmud Y, Adhikary RK, Rahman SBM, Haq MS, Rashid H (2015) Chemical profile and heavy metal concentration in water and freshwater species of Rupsha River, Bangladesh. Am J Environ Prot 3(6):180-186. https://doi.org/10.12691 lenv-3-6-1

19. Javed M, Usmani $N$ (2013) Assessment of heavy metal $(\mathrm{Cu}, \mathrm{Ni}$, $\mathrm{Fe} \mathrm{Co}, \mathrm{Mn}, \mathrm{Cr}, \mathrm{Zn}$ ) pollution in effluent dominated rivulet water and their effect on glycogen metabolism and histology of Mastacembelus armatus. Spingerplus 2(390):7-13

20. Shahidul Islam M et al (2018) Physico-chemical assessment of water quality parameters in Rupsha River of Khulna Region, Bangladesh. Int J Eng Sci 7(1):57-62 
21. Kibria G et al (2016) Monitoring of metal pollution in waterways across Bangladesh and Ecological and public health implications of pollution. Chemosphere 165:1-9. https://doi. org/10.1016/j.chemosphere.2016.08.121

22. Bangladesh Population Census (2001) Bangladesh Bureau of Statistics; Cultural survey report of Abhaynagar Upazila 2007

23. Association of Analytical Communities (AOAC) (2000) Official methods of analysis, 17th edn. Association of Official Analytical Chemists, Gaithersburg

24. WHO (World Health Organization) (2011) Guidelines for drinking water quality-1, recommendations, 4th edn. World Health Organization, Geneva

25. APHA (American Public Health Association) (2005) Standard methods for examination of water and wastewater, 21 st edn. APHA, Washington, pp 15-36

26. You ZJ, Lu JX, Liu YY (2009) The improvement of calculation formula of comprehensive pollution index. Neiminer Environ Sci 21:101-102
27. Heikins A (2006) Arsenic contamination of irrigation water, soil and crops in Bangladesh: risk implications for sustainable agriculture and food safety in Asia. FAO Regional Office for Asia and Pacific, Bangkok

28. Department of Environment (DOE) (1997) Environmental quality standards (EQS) for Bangladesh. Department of Environment (DOE), Government of Bangladesh, Dhaka

29. ATSDR (2000) Toxicological profile for manganese. U.S. Department of Health and Human Services, Public Health Service, Agency for Toxic Substances and Disease Registry, Atlanta

30. Keen CL, Ensunsa JL, Clegg MS (2000) Manganese metabolism in animals and humans including the toxicity of manganese. Met lons Biol Syst 37:89-121

Publisher's Note Springer Nature remains neutral with regard to jurisdictional claims in published maps and institutional affiliations. 